\title{
Acceptabiliteit als element voor de bruikbaarheid van toetsen: de elementen die voor studenten wegen
}

\author{
P. van der Harst, G.A.H. Buist, W. Tulp, E. Meijer, T.E. Ettema, J. Cohen-Schotanus
}

\section{Samenvatting}

Inleiding: Kwaliteit van toetsing is een essentieel aspect van een goede opleiding. Om dat te bewaken is onder meer aandacht voor psychometrische aspecten en kostenbeheersing nodig. Echter, voor de bruikbaarheid van de toets is het ook van belang om aandacht te hebben voor de -acceptabiliteit' of aanvaardbaarheid ervan. Doel van dit onderzoek is de exploratie van het begrip 'acceptabiliteit van toetsing' door studenten. Daarnaast wordt een korte vragenlijst ontwikkeld die de aanvaardbaarheid van verschillende toetsvormen kan meten als onderdeel van de kwaliteitscyclus van het onderwijs.

Methode: In een focusgroepdiscussie werd het begrip 'acceptabiliteit van toetsing' geëxploreerd. Hieruit ontstond een gestructureerde vragenlijst met 37 onderwerpen die voorgelegd werd aan studenten geneeskunde aan de Rijksuniversiteit Groningen. Met behulp van factoranalyse werden vragen geclusterd, waardoor datareductie mogelijk werd.

Resultaten: De vragenlijst werd ingevuld door 814 respondenten (79\%). De acceptabiliteit van een toets door studenten omvat vier dimensies: kwaliteit, grip op de leerstof, omgeving en helderheid. Door datareductie ontstond een korte vragenlijst met 8 items.

Discussie: In discussies over de kwaliteit van een toets wordt weinig rekening gehouden met de mening van studenten. In dit onderzoek is onderzocht welke dimensies voor studenten van invloed zijn op hun oordeel over de toets. Deze dimensies zijn de basis voor een korte evaluatiemethode en kunnen naast bestaande methoden gebruikt worden om de kwaliteit van de toetsen verder te verbeteren. (Harst P van der, Buist GAH, Tulp W, Meijer E, Ettema TE, Cohen-Schotanus J. Acceptabiliteit als element voor de bruikbaarheid van toetsen: de elementen die voor studenten wegen. Tijdschrift voor Medisch Onderwijs 2005;24(1):24-34.)

\section{Inleiding}

Kwaliteit van toetsing is een essentieel aspect van het onderwijs. De gekozen toetsmethode en de wijze van afname zijn nauw gerelateerd aan de manier waarop studenten leren. ${ }^{1-2}$ De ontwikkeling van congruente toetsstrategieën voor pedagogische principes en leergedrag is daarom terecht een belangrijk onderdeel geworden van curriculumontwikkeling. De afgelopen jaren hebben vooral psychometrische aspecten en kostenbeheersing de aandacht gekregen bij de toetsontwikkeling, wat geleid heeft tot toename van de betrouwbaarheid, validiteit en effectiviteit. Al in 1982 onderkenden Verwijnen et al. bij de beschrijving van het medisch curriculum in Maastricht dat een eenzijdige facultaire benadering van toetsing inconsequent is bij een 'studentgeoriënteerde' filosofie. ${ }^{3}$ In 1995 beschreef Van der Vleuten een formule voor de bruikbaarheid (utiliteit) van een toetsmethode. ${ }^{4}$ De formule geeft de relatie aan tussen een vijftal elementen die van belang zijn bij het vaststellen van een toetsprogramma:

$$
\mathrm{U}=\mathrm{B}_{\mathrm{w}} \times \mathrm{V}_{\mathrm{w}} \times \mathrm{O}_{\mathrm{w}} \times \mathrm{A}_{\mathrm{w}} \times \mathrm{K}_{\mathrm{w}}
$$

Utiliteit (U) is een functie van de betrouwbaarheid (B), validiteit (V), onderwijsconsequenties (O), acceptabiliteit (A) 
en kosten (K). Aan elk van deze elementen kan een bepaald gewicht worden toegekend $\left({ }_{\mathrm{w}}\right)$.

De onderliggende relatie is multiplicatief: als een der elementen nul is, zal de uiteindelijke bruikbaarheid nul zijn. Het is geen mathematische formule, maar een conceptueel model dat een rationele discussie toelaat over het belang van elk van de elementen in een concrete situatie. ${ }^{4}$ Het samenstellen van een toetsprogramma is een compromis, waarbij het toegekende gewicht aan de elementen leidt tot een beargumenteerde beslissing voor de keuze van de beoordelings- of toetsmethode. De meeste elementen uit het model kunnen vrij objectief onderbouwd worden; redelijkerwijs liggen de belangen van de onderwijsorganisatie, docenten en studenten niet ver uit elkaar. Het element 'acceptabiliteit' echter laat meer subjectiviteit toe. Het wordt bepaald door tradities en de intuïtie van docenten: argumenten zijn niet altijd rationeel te benaderen. Dit leidt ertoe dat een toetsmethode in voldoende mate door docenten geaccepteerd moet worden om succesvol te zijn.

Maar hoe zit het met de acceptabiliteit van studenten voor een toetsmethode? Wordt deze ook meegenomen bij de beslissing? In de kwaliteitscyclus van het onderwijs is er zeker plaats voor opvattingen van studenten over beoordelings- en toetsmethoden. Maar welke zijn dit en hoe kunnen deze meegewogen worden?

Een eerste stap daartoe is het beschrijven van de heersende opvattingen over toetsen bij studenten van de Faculteit der Medische Wetenschappen (FMW) in Groningen. Het operationaliseren van het element 'acceptabiliteit' binnen de utiliteitsformule, vanuit het perspectief van studenten geneeskunde, is dan ook de doelstelling van dit onderzoek. Met de uitkomst hiervan kan mogelijk een methode beschreven worden om de acceptabiliteit van specifie- ke toetsvormen mee te wegen bij de discussie over de bruikbaarheid ervan.

\section{Methode}

Voor het operationaliseren van het begrip 'acceptabiliteit van toetsing' werd gestart met een focusgroepinterview. Tijdens een focusgroepinterview (discussie) wordt in korte tijd het gezichtpunt van een groep over een bepaald onderwerp afgetast. De focusgroep bestond uit zeven actieve studenten van de facultaire studievereniging ProMed en een onderwijskundige van het onderwijsinstituut van de FMW te Groningen. Na een toelichting over de bedoeling van de bijeenkomst werden twee samenhangende vragen voorgelegd aan de groep:

1. Welke aspecten bepalen jouw voorkeur of tegenzin voor een bepaalde toetsmethode?

2. Welke aspecten beïnvloeden (positief of negatief) jouw kijk op een toets?

Ter ondersteuning werden de gebruikte toetsmethoden bij de faculteit op een flapover gezet.

De discussie werd gestructureerd door het brainstormmodel (divergentie/convergentie). Aan het eind van de discussie waren 37 aspecten benoemd in samenhang tot het begrip 'acceptabiliteit van toetsing'. De aspecten hadden betrekking op de organisatie, de omvang en beschikbare tijd, de representativiteit, de kwaliteit, de beoordeling en de consequentie van toetsing. De 37 aspecten vormden de basis voor het opstellen van een gestructureerde vragenlijst die als volgt ingedeeld was:

- Demografische gegevens.

- Aspecten die spelen voor aanvang van de toets.

- Informatie over de toets.

- Aspecten die spelen tijdens de toets.

- Randvoorwaarden bij de toets.

- Aspecten die spelen na afloop van de toets. 
Bij de vragenlijst werd eerst het doel van het onderzoek uitgelegd, daarna werd aan de studenten gevraagd om aan te geven in welke mate genoemd aspect invloed heeft op het persoonlijk oordeel over de toets of toetsmethode. De studenten konden antwoorden op een 5-punts Likert-schaal met als uitersten: weinig invloed - veel invloed.

De populatie voor dit surveyonderzoek bestond uit alle studenten geneeskunde (jaar 1 tot en met jaar 6) ingeschreven bij de FMW in Groningen. Om een zo hoog mogelijke respons te krijgen en aan te sluiten bij de actualiteit van het toetsen, werd de vragenlijst uitgereikt tijdens een voortgangstoets (september 2002) in Groningen. De voortgangstoets is een verplicht examenonderdeel, waardoor bijna alle studenten in de tentamenhal aanwezig zijn. Studenten die in een affiliatieziekenhuis de co-schappen liepen of tijdelijk in het buitenland verbleven, werden hierdoor niet betrokken in het onderzoek. Het invullen van de vragenlijst was anoniem, kostte hooguit tien minuten en interfereerde niet met de maximaal beschikbare tijd voor de Voortgangstoets.

De analyses berusten op beschrijvende statistiek en non-parametrische toetsen. Met de toetsen werd nagegaan of gevonden verschillen bij het oordeel over toetsing samenhangt met geslacht (MannWhitney-toets) of studiefase (KruskalWallis-toets). Tot slot werd op de dataset een factoranalyse (Principal Component Analysis) uitgevoerd met als doel samenhangende vragen te clusteren die vervolgens als basis konden dienen voor het ontdekken van onderliggende dimensies van het begrip 'acceptabiliteit van toetsing' door studenten.

\section{Resultaten}

Tijdens de voortgangstoets werden 1030 vragenlijsten uitgedeeld; 814 (79\%) werden ingevuld geretourneerd. De verdeling
Tabel 1. Verdeling van respondenten naar geslacht, leeftijd en studiejaar.

\begin{tabular}{|c|c|c|}
\hline & $\mathbf{N}$ & $\%$ \\
\hline Populatie & 1030 & \\
\hline Respons & 814 & $(79 \%)$ \\
\hline \multicolumn{3}{|l|}{ Geslacht } \\
\hline Vrouw & 521 & $(64 \%)$ \\
\hline Man & 293 & $(36 \%)$ \\
\hline Leeftijd in jaren (SD) & 22 & $(2,6)$ \\
\hline \multicolumn{3}{|l|}{ Verdeling naar studiejaar } \\
\hline 1ejaars & 244 & $(30 \%)$ \\
\hline $2^{\mathrm{e}}$ jaars & 179 & $(22 \%)$ \\
\hline $3^{\mathrm{e}}$ jaars & 187 & $(23 \%)$ \\
\hline $4 \mathrm{e}_{j a a r s}$ & 98 & $(12 \%)$ \\
\hline $5^{\mathrm{e}}$ jaars & 73 & (9\%) \\
\hline $6^{\mathrm{e}}$ jaars & 33 & $(4 \%)$ \\
\hline
\end{tabular}

van de respondenten naar geslacht, studiejaar, co-assistentschap en voltooiing van de wetenschappelijke stage zijn beschreven in tabel 1. De respons is een representatieve afspiegeling van de populatie.

De antwoorden die de studenten gaven in de vragenlijst zijn opgenomen in tabel 2. Hoewel het ordinale data betreft, zijn hiervoor toch gemiddelden berekend. Visueel geven deze een beter overzicht. Uiteraard werden mogelijke verschillen getoetst met non-parametrische toetsen. De gemiddelde scores zijn gepresenteerd als totaalscore en uitgesplitst naar studiejaar en geslacht. De resultaten in de tabel geven een indicatie van de aspecten die studenten meer of minder belangrijk vinden bij hun oordeel over een toets. Het betreft de kwaliteit van de toets, het bevragen van kernpunten uit de leerstof, de representativiteit van de vragen, dat in de toets kennis wordt bevraagd en de formulering van de opdracht of de helderheid van de vraagstelling. Verder moet de toets relevant zijn voor de opleiding tot arts en moet je kunnen laten zien wat je kunt/weet (vragen 15, 16, 18, 19, 22, 23 en 20). Ook de vragen over objectieve normering en beoordeling en de vraag of het 
eindcijfer overeenkomt met de eigen verwachting zijn belangrijk bij de oordeelsvorming over een toets (vragen 30, 31 en 35). De randvoorwaardelijke aspecten zoals de toetsruimte, temperatuur en afleidende factoren (vragen 26, 27 en 28) hebben minder invloed op het uiteindelijke oordeel over een toets. In de vragenlijst werd de vraag over de 'consequentie van het resultaat op de toets' in twee verschillende contexten gesteld (vragen 11 en 32). De antwoorden laten een consistent beeld zien.

\section{Verschillen tussen jaargroepen}

De eerstejaars studenten gaven aan dat de plaats van een toets in het tentamenrooster (vraag 4) met een score van 3,2 een grotere invloed heeft op hun oordeel over de toets dan bij de overige studenten met een score van 2,7 (significant). Voor studenten uit de studiejaren 1 en 2 was de 'duur/lengte van de toets (vraag 9) echter van minder belang bij hun oordeel dan bij studenten uit de studiejaren 5 en 6. De overige vragen werden door de studenten uit de verschillende studiejaren over het algemeen op de zelfde wijze gewaardeerd.

\section{Verschillen tussen studenten in de klinische fase en overige studenten}

Studenten in de klinische fase gaven met een 4,4 aan dat de relevantie voor het beroep (vraag 18) een significant grotere invloed heeft op hun oordeel over de toets dan bij de overige studenten met een 4,1 (Kruskal-Wallis-toets $-\mathrm{p}<0,001$ ). Verdere waren er verschillen tussen studenten in de klinische fase en overige studenten bij vraag 30 over de objectiviteit van de normering (een waardering van 4,2 tegen 4,0) en bij vraag 31 over de objectiviteit van de beoordelaar (een waardering van 4,2 tegen 4,0 ) en het gewicht van een toets in het eindcijfer (een waardering van 3,7 tegen 3,5 ).

\section{Verschillen tussen geslachten}

Bij een vergelijking tussen vrouwelijke en mannelijke studenten valt op dat vrouwen over het algemeen een iets hoger gemiddelde hebben. Dit geldt vooral bij de vragen over 'aspecten tijdens de toets' (tabel 2). Bij de vragen 20, 21 en 35, respectievelijk "Je kunt laten zien wat je kunt/weet", "Niveau van de toets" en "Eindcijfer komt overeen met eigen verwachting", zijn de verschillen statistisch significant (MannWhitney-toets $-\mathrm{p}<0,001$ ); de vrouwen vinden meer dan mannen dat deze aspecten invloed hebben op hun oordeel over de toets. De overige verschillen tussen vrouwen en mannen zoals 'het hebben van voldoende voorbereidingstijd' en 'het bevragen van kernpunten' zijn statistisch niet significant.

\section{Factoranalyse en itemreductie}

Factoranalyse werd toegepast om vragen met gemeenschappelijke kenmerken of onderliggende dimensies te clusteren. De gesommeerde scores van de clusters maken het mogelijk om er een gewicht aan toe te kennen. De factorlading geeft de bijdrage weer van de variabele binnen het cluster, de verklarende variantie de sterkte van het gehele cluster. Het is mogelijk dat een variabele binnen twee clusters een redelijk gelijke bijdrage levert. Op basis van inhoudelijke argumenten wordt de variabele dan toegewezen aan een van beide clusters. De factoranalyse, de Principal Component-methode met Varimax Rotation, identificeerde 4 factoren. In tabel 3 zijn alleen de factorladingen $>0,3$ bij de vraag weergegeven; onderaan de tabel is het percentage verklarende variantie van de factor vermeld. De vragen die door de factoranalyse geclusterd zijn, lijken inhoudelijk met elkaar een dimensie te vertegenwoordigen. Factor 1 wordt door ons omschreven als 'kwaliteit van de toets'. Het gaat hierbij om de aard of eigenschap 


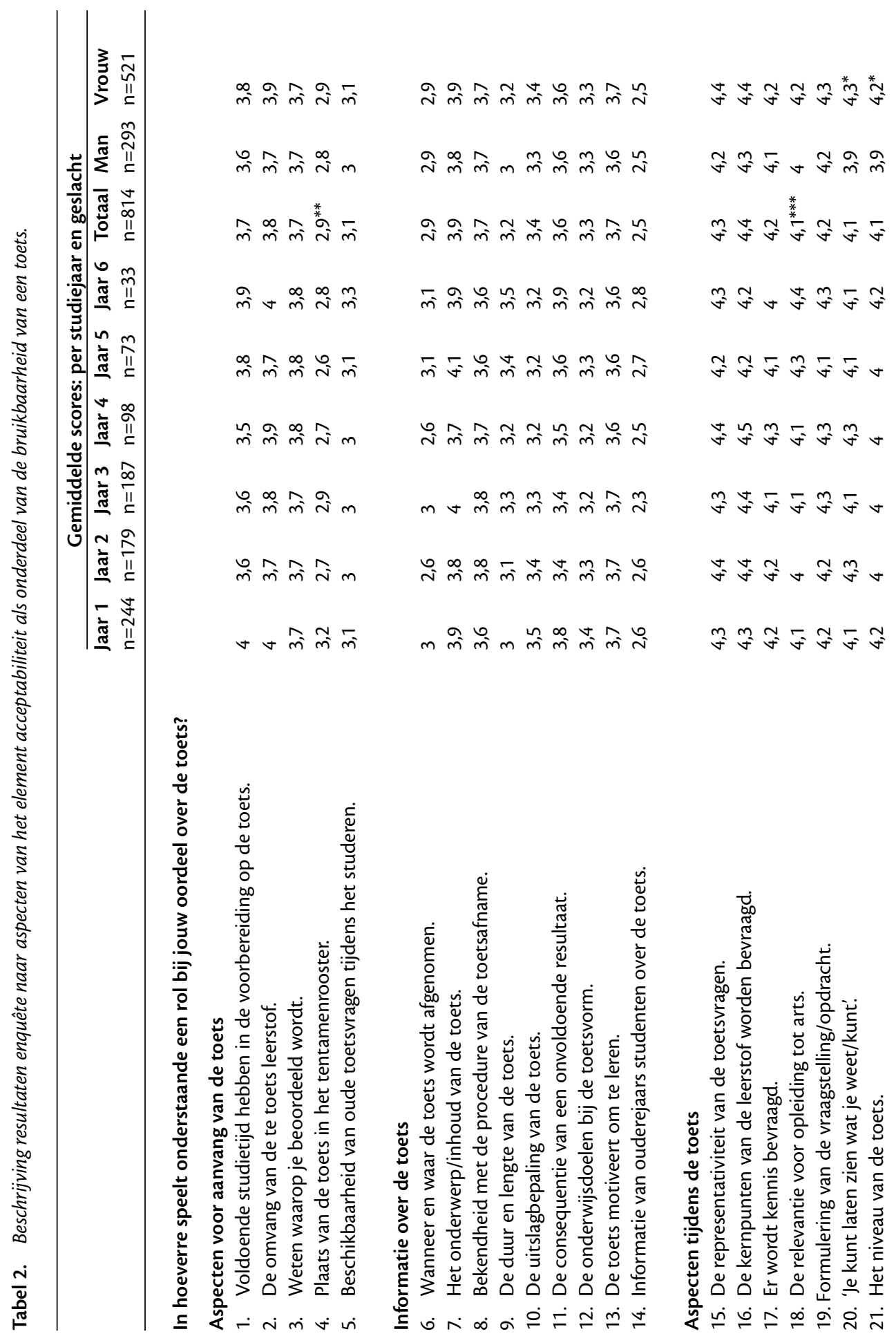




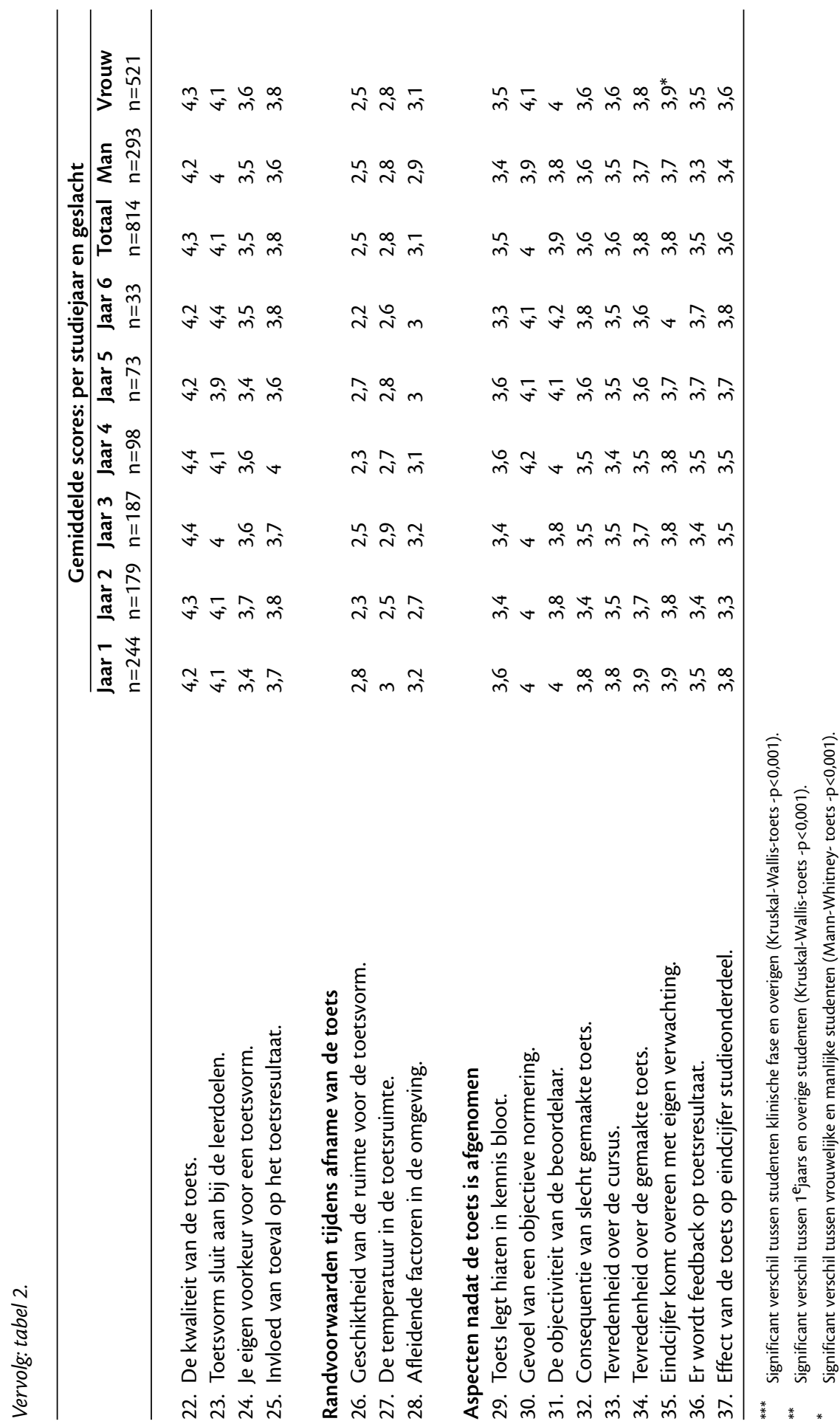


van de toets, doet de toets waarvoor deze is bedoeld: het op een inhoudsvalide en betrouwbare wijze evalueren van de studievoortgang van studenten. Factor 2 wordt omschreven als 'grip op de studie'. Hierbij gaat het om het evenwicht tussen de hoeveelheid leerstof en de beschikbare studietijd, en de mogelijkheid voor studenten om een relatie te leggen tussen het eigen studiegedrag en het resultaat op de toets. De derde factor heeft betrekking op de 'omgeving' waarin de toets wordt afgenomen: kan de student zich concentreren op de toets zonder afgeleid te worden door externe factoren. De vierde factor heeft betrekking op 'helderheid', d.w.z. of de student beschikt over relevante en juiste informatie over datgene wat verwacht kan worden tijdens de toets. Dit betreft ook de wijze waarop de beoordeling tot stand komt.

De geclusterde factoren laten een inhoudelijke samenhang zien. Dit maakt het mogelijk om datareductie toe te passen door het samenvoegen of schrappen van vragen. Door datareductie ontstond een korte vragenlijst (tabel 4) waarmee het concept acceptabiliteit van een toetsmethode eenvoudiger te bepalen is. De vragen met de hoogste mediaan per factor werden gebruikt als uitgangspunt. De verklarende variantie bepaalde het gewicht per cluster, wat ook tot uitdrukking komt in het aantal vragen.

\section{Discussie}

Voor de acceptabililiteit van toetsmethoden, zoals beschreven door Van der Vleuten, ${ }^{4}$ was vooralsnog geen heldere beschrijving beschikbaar. Het bleef een moeilijk te definiëren begrip dat ruimte gaf aan een persoonlijke, subjectieve interpretatie. Studenten werden tijdens evaluaties wel regelmatig gevraagd naar hun mening over de toets, maar door gebrek aan structurering is interpretatie lastig.
De bijdrage aan de kwaliteitsbewaking van toetsen blijft daardoor gering.

In dit onderzoek is een poging ondernomen om het begrip 'acceptabiliteit van toetsing' vanuit het perspectief van studenten geneeskunde vorm te geven. $\mathrm{Na}$ een focusgroepdiscussie is aan deze studenten gevraagd welke aspecten invloed hebben op hun oordeel over de toets. Het blijven persoonlijke en subjectieve meningen, maar door de grote respons $(n=814)$ neemt de intersubjectiviteit toe en dient er toch enige betekenis aan dit oordeel gegeven te worden.

De belangstelling voor de mening van studenten over toets- en beoordelingsmethoden blijkt ook uit enkele recente publicaties. In Leicester ${ }^{5}$ kwam men na een onderzoek onder studenten tot de conclusie dat er een relatie is tussen de 'face validity' van een toets voor een examen en de waarde die studenten hechten aan de uitkomsten van dat examen. Ongeacht de werkelijke betrouwbaarheid en validiteit van een toets wordt de mening gevormd door de subjectieve beleving. Dit komt overeen met Van der Vleuten's ${ }^{4}$ opvatting dat toets- en beoordelingsvormen die door docenten niet geaccepteerd zijn, beter vermeden kunnen worden. In Newcastle $^{6}$ werden studenten geënquêteerd over de eerlijkheid van de beoordelingsmethode van een toets. Eerlijkheid van de toetsmethode werd opgevat als een belangrijk criterium voor de bruikbaarheid van een toets. Uit de conclusie kwam naar voren dat een ervaren oneerlijke beoordeling een negatief effect had op het oordeel over de bruikbaarheid.

Een bruikbare toets had echter meer nodig dan alleen een eerlijke beoordeling. Uit het huidige onderzoek blijkt dat studenten het begrip 'acceptabiliteit van toetsing' vanuit vier factoren of dimensies betekenis geven. De eerste en sterkste dimensie wordt omschreven als 'de kwaliteit 
Tabel 3. Factoranalyse (Pricipal Component Analysis en Varimax Rotation) op de vragenlijst over de acceptabiliteit van toetsing.

\begin{tabular}{|c|c|c|c|c|}
\hline Vraag & Factor 11 & Factor $2^{2}$ & Factor $3^{3}$ & Factor $4^{4}$ \\
\hline 16. De kernpunten van de leerstof worden bevraagd. & 0,814 & & & \\
\hline 22. De kwaliteit van de toets. & 0,793 & & & \\
\hline 15. De representativiteit van de toetsvragen. & 0,783 & & & \\
\hline 17. Er wordt kennis bevraagd. & 0,758 & & & \\
\hline 20. 'Je kunt laten zien wat je weet/kunt'. & 0,741 & & & \\
\hline 23. Toetsvorm sluit aan bij de leerdoelen. & 0,722 & & & \\
\hline 21. Het niveau van de toets. & 0,699 & & & \\
\hline 19. Formulering van de vraagstelling/opdracht. & 0,69 & & & \\
\hline 18. De relevantie voor opleiding tot arts. & 0,678 & & & \\
\hline 30. Gevoel van een objectieve normering. & 0,665 & & & \\
\hline 31. De objectiviteit van de beoordelaar. & 0,497 & & 0,355 & \\
\hline 36. Er wordt feedback op toetsresultaat. & 0,474 & 0,317 & & \\
\hline 13. De toets motiveert om te leren. & 0,434 & & & \\
\hline 35. Eindcijfer komt overeen met eigen verwachting. & 0,432 & 0,514 & & \\
\hline 12. De onderwijsdoelen bij de toetsvorm. & 0,431 & & & \\
\hline 29. Toets legt hiaten in kennis bloot. & 0,426 & & & \\
\hline 25. Invloed van toeval op het toetsresultaat. & 0,394 & & & \\
\hline 3. Weten waarop je beoordeeld wordt. & 0,389 & & & 0,417 \\
\hline 34. Tevredenheid over de gemaakte toets. & 0,386 & 0,656 & & \\
\hline 24. Je eigen voorkeur voor een toetsvorm. & 0,354 & & & 0,308 \\
\hline 32. Consequentie van slecht gemaakte toets. & & 0,736 & & \\
\hline 37. Effect van de toets op eindcijfer studieonderdeel. & & 0,703 & & \\
\hline 11. De consequentie van een onvoldoende resultaat. & & 0,636 & & \\
\hline 33. Tevredenheid over de cursus. & & 0,593 & & \\
\hline op de toets. & & 0.551 & & \\
\hline 2. De omvang van de te toets leerstof. & & 0,546 & & \\
\hline 27. De temperatuur in de toetsruimte. & & & 0,839 & \\
\hline 26. Geschiktheid van de ruimte voor de toetsvorm. & & & 0,831 & \\
\hline 28. Afleidende factoren in de omgeving. & & & 0,698 & \\
\hline 6. Wanneer en waar de toets wordt afgenomen. & & & 0,564 & \\
\hline 4. Plaats van de toets in het tentamenrooster. & & & 0,367 & 0,382 \\
\hline 9. De duur en lengte van de toets. & & & 0,308 & 0,588 \\
\hline \multicolumn{5}{|l|}{ 5. Beschikbaarheid van oude toetsvragen tijdens } \\
\hline het studeren. & & & & 0,447 \\
\hline 7. Het onderwerp/inhoud van de toets. & & & & 0,335 \\
\hline 8. Bekendheid met de procedure van de toetsafname. & & & & 0,634 \\
\hline 10. De uitslagbepaling van de toets. & & & & 0,635 \\
\hline 14. Informatie van ouderejaars studenten over de toets. & & & & 0,445 \\
\hline Eigenwaarde & 7,487 & 3,767 & 2,889 & 2,492 \\
\hline$\%$ van variantie & 20,235 & 10,182 & 7,808 & 6,735 \\
\hline
\end{tabular}

\footnotetext{
1 Factor 1 = de kwaliteit van de toets.

${ }^{3}$ Factor 3 = de omgeving waarin de toets wordt afgenomen. 
Tabel 4. Dimensies en onderliggende aspecten van het element 'acceptabiliteit' van een toets door studenten.

\begin{tabular}{ll}
\hline Dimensie & Aspecten; de vragen in het verkorte instrument \\
\hline Kwaliteit van de toets & $\begin{array}{l}\text { De toets bevraagt kernpunten van de lesstof en is representatief. } \\
\text { De toets geeft gelegenheid "te laten zien wat je weet/kunt". } \\
\text { De beoordeling van de toets is objectief. } \\
\text { De toetsitems zijn helder en eenduidig geformuleerd. }\end{array}$ \\
Grip op de studie & $\begin{array}{l}\text { De omvang van de toetsstof is acceptabel voor de beschikbare studietijd. } \\
\text { De toets levert een eindcijfer op dat overeenkomt met de eigen verwachting. }\end{array}$ \\
Omgeving & $\begin{array}{l}\text { Bij het maken van de toets is er geen afleiding door andere zaken. } \\
\text { Helderheid }\end{array}$ \\
& $\begin{array}{l}\text { Weten wat je kunt verwachten tijdens de toets, openheid van toetsprocedure } \\
\text { en beoordelingscriteria. }\end{array}$ \\
\hline
\end{tabular}

van de toets' en wordt gedragen door de begrippen inhoudsvalide en betrouwbaar. De studenten willen een goede toets, een toets die een appèl doet op hun verworven kennis tijdens deze studieperiode. Tevens vinden zij dat de beoordeling eerlijk (rechtvaardig) dient te zijn, dat de vragen helder en eenduidig geformuleerd moeten zijn, en dat zij relevant en representatief dienen te zijn voor de studiestof in de achterliggende studieperiode. Deze eigenschappen zijn ook onderdeel van de elementen 'validiteit' en 'betrouwbaarheid' in de utiliteitsformule, maar hier gaat het mogelijk toch meer om 'face validity' of 'ervaren validiteit': straalt de toetsmethode wel uit dat deze valide en betrouwbaar is. Bijvoorbeeld bij een MCQ-toets kunnen achteraf slecht geformuleerde vragen verwijderd worden en bij een stationstoets kan een slecht geconstrueerde opdracht niet meegenomen worden bij de uitslagbepaling. Psychometrisch gezien zal de validiteit en betrouwbaarheid van de toets hierdoor toenemen. Dit geldt niet voor de ervaren validiteit; deze zal door een dergelijke verbetering achteraf mogelijk negatief beïnvloed worden.

Verder is het van belang dat studenten een relatie kunnen leggen tussen inspanning en resultaat (factor 2: 'Grip op studie'). Zij moeten een verband zien tussen de mate van beheersing van de leerstof (naar 'eigen opvatting') en het uiteindelijke toetsresultaat. Er is dan een positief verband tussen het onderwijsprogramma, studiegedrag en toetsresultaat, omdat de toets discrimineert tussen 'echt weten' en 'niet weten'. In het verlengde hiervan moeten studenten die hun studiegedrag vooral richten op het bestuderen van oude toetsen niet in het voordeel zijn doordat er veel vragen zijn overgenomen uit oude toetsen. Bij de tweede factor speelt ook nog mee de omvang van de studiestof ofwel de studeerbaarheid.

De derde en vierde factor lijken een wat minder sterke invloed te hebben op het oordeel over de toets. Factor 3 'Omgeving' ligt voor de hand. Als studenten bezig zijn met de toets willen ze niet afgeleid worden door zaken die niets met de toets te maken hebben. Factor 4 'helderheid' zit wat meer in de voorbereidende fase van de toets. Studenten vinden het belangrijk dat er vooraf voldoende helderheid bestaat over de beoordelings- en toetsmethode. Dit heeft wel invloed op het oordeel over de toets, maar is mogelijk vooraf te corrigeren.

De acceptabiliteit lijkt bij alle factoren duidelijk subjectief geladen. Studenten zijn het echter wel eens met elkaar over de mate waarin ze invloed hebben op het 
oordeel over de toets. Hoewel acceptabiliteit als onderdeel van de utiliteitsformule gericht is op docenten, vormt een discrepantie tussen hun interpretatie en die van studenten ook een bedreiging voor de bruikbaarheid van de toets- of beoordelingsmethode.

Bij de resultaten worden enkele statistisch significante verschillen beschreven bij de jaargroepen, studiefase en geslacht. De verschillen zijn gering en geven weinig praktische relevantie. Het is verklaarbaar dat eerstejaars studenten de plaats van een toets in het tentamenrooster belangrijker vinden dan ouderejaars; onzekerheid aan het begin van een nieuwe studie ligt hier mogelijk aan ten grondslag. Studenten in de klinische fase leggen meer nadruk op de klinische herkenbaarheid en de context van de vraagstelling. Dit is immers hun dagelijkse praktijk geworden. Ook het belang dat zij hechten aan de objectiviteit van de beoordelaar en beoordeling past binnen de praktijk van de co-assistent, waarin beoordelingen veelal gebaseerd zijn op waarnemingen en interacties.

Ook de verschillen op basis van geslacht zijn niet opzienbarend. Overeenkomstige man/vrouw-verschillen worden gevonden in onderzoek naar leerstijlen en effectiviteit van het onderwijs.

$\mathrm{Na}$ factoranalyse konden vier dimensies uit de 37 voorgelegde vragen onderscheiden worden (kwaliteit van de toets, grip op de studie, context en helderheid). Op basis van statistische waarden (factorlading, mediaan en verklarende variantie) werd een verkorte vragenlijst samengesteld. Deze vragenlijst kan voor alle toetsmethoden (stationstoetsen, klinisch redeneren, mondeling examen, MC-vragen et cetera) op ieder evaluatiemoment afgenomen worden. Hiermee wordt vergelijkbare en toetsspecifieke informatie gegenereerd. Dat maakt het mogelijk om acceptabiliteit vanuit het studentenperspectief mee te wegen in de discussie over de bruikbaarheid van toetsen beoordelingsmethoden. Dit korte evaluatie-instrument is een aanvulling op bestaande psychometrische toetsanalyses en draagt verder bij aan de kwaliteitsverbetering van een facultair-breed gedragen toetsprogramma.

Deze studie laat zien dat het praktisch haalbaar is om data te verzamelen over de acceptabiliteit van toetsen. Ongetwijfeld zijn er nog tal van vragen die mogelijk door vervolgonderzoek beantwoord kunnen worden. Van essentieel belang daarbij zijn de validiteit en betrouwbaarheid van het instrument en de onafhankelijkheid ten opzichte van andere dimensies van evaluaties.

\section{Literatuur}

1. Godfrey RC. Undergraduate examinations - a continuing tyranny. Lancet 1995;345:765-7.

2. Vleuten CPM van der. The assessment of professional competence: developments, research and practical implications. Adv Health Sci Educ 1996;1:41-67.

3. Verwijnen M, Imbos T, Snellen H, Stalenhoef B, Pollemans M, Luyk S van, et al. The evaluation system at the Medical School of Maastricht. Assessment Evaluation Higher Education 1982;7:225-44.

4. Vleuten CPM van der. Toetsing van medische competenties. In: Metz JCM, Scherpbier AJJA, Vleuten CPM van der [editors]. Medisch onderwijs in de praktijk. Assen: Van Gorcum; 1995. p. 152-64.

5. Tweed M, Cookson J. The face validity of a final professional clinical examination. Med Educ 2001;35:465-73.

6. Duffield KE, Spencer JA. A survey of medical students' views about the purposes and fairness of assessment. Med Educ 2002;36:879-86.

De auteurs

Drs. P. van der Harst is student geneeskunde.

Drs. G.A.H. Buist is stafmedewerker aan het Onderwijsinstituut.

Mw. W. Tulp is student geneeskunde.

Mw. E. Meijer is student geneeskunde.

Dhr. T.E. Ettema is student geneeskunde.

Mw. dr. J. Cohen-Schotanus is hoofd van de afdeling Onderwijsontwikkeling en Kwaliteitszorg van het Onderwijsinstituut.

Allen zijn verbonden aan de Faculteit der Medische Wetenschappen van de Rijksuniversiteit Groningen. 
Correspondentieadres:

Drs. P. van der Harst, Academisch Ziekenhuis Groningen, Hanzeplein 1, 9700 RB Groningen, tel. 0503614734,p.van.der.harst@thorax.azg.nl.

\section{Summary}

Introduction: High quality assessment is a prerequisite for successful education. Recent assessment research focused predominately on psychometric aspects and budget control. Acceptability is also a crucial factor in determining the quality of assessment, however. The objective of the present study was to operationalise the concept of "acceptability" of assessment to medical students. Furthermore, we aimed to develop a method to include acceptability in measures to improve the quality of assessment.

Methods: A structured 37-item questionnaire was designed after a panel group discussion. Students of Groningen Medical School were surveyed. Subgroup analyses and factor analyses were performed to develop a short, representative questionnaire.

Results: 814 students (79\%) completed the survey. The mean age was 22 years, $4 \%$ of the students were female and 16\% were doing clinical clerkships. Four dimensions of acceptability of assessment were identified: quality of the test, control of study objectives, environment and clarity. An 8-item questionnaire was designed to evaluate acceptability.

Conclusion: Currently, not enough attention is paid to the acceptability of tests to students in quality control of assessment. As a first step towards incorporating acceptability in the quality control process, we performed a large-scale student survey to establish dimensions of acceptability. We used these dimensions to develop an 8-item questionnaire that can be used in quality control surveys. (Van der Harst P, Buist GAH, Tulp W, Meijer E, Ettema TE, Cohen-Schotanus J. Acceptability as a crucial factor in determining the quality of assessment: the elements considered to be of importance by students. Dutch Journal of Medical Education 2005;24(1):2434.) 